\title{
Experimental Study of the Drying Kinetics of Mango (mangifera indica L.) during Airflow Drying Licking Countercurrent
}

\author{
Ekani Roger Yannick, Tetang Fokone Abraham, Edoun Marcel, Kuitche Alexis \\ Laboratory of Energetic and Applied Thermal (LETA), ENSAI - Ngaoundere, \\ The University of Ngaoundere, P.O. Box 455, Cameroon \\ *Corresponding author: abramtetang@yahoo.fr
}

Received April 17, 2019; Revised May 24, 2019; Accepted June 10, 2019

\begin{abstract}
This work was conducted to study the thin-film drying kinetics of mango (mangifera indica L.) using a modular electrical dryer licking countercurrent and forced convection. Drying experiments were carried out in the Laboratory of Energetics and Applied Thermal (LETA) of the National School of Agro-Industrial Sciences of the University of Ngaoundere under different conditions of drying air temperature $\left(40,50\right.$ and $\left.60^{\circ} \mathrm{C}\right)$ for a speed $0.6 \mathrm{~m} / \mathrm{s}$. Four trays were used to spread the products in the dryer. To estimate and select the appropriate drying model, ten different models were applied to the experimental data and compared. The performances of these models were compared using the $\mathrm{R}^{2}$, the $\chi^{2}$ and the RMSE between the observed and predicted moisture ratios values, which ranged from 0.925 to $0.999 ; 4.10^{-6}-0.00540$ and $0.0021-0.0736$ respectively. Among the models used, the Midilli et al., model was found to best explain the thin-film drying airflow drying licking countercurrent of mango.
\end{abstract}

Keywords: licking drying, countercurrent, drying kinetics, mango, water content

Cite This Article: Ekani Roger Yannick, Tetang Fokone Abraham, Edoun Marcel, and Kuitche Alexis, "Experimental Study of the Drying Kinetics of Mango (mangifera indica L.) during Airflow Drying Licking Countercurrent." American Journal of Food Science and Technology, vol. 7, no. 4 (2019): 127-132. doi: 10.12691/ajfst-7-4-4.

\section{Introduction}

Population growth implies an increase in food consumption. In order to cope with the latter, populations are increasingly found in the agricultural sector. In many African countries, where food self-sufficiency remains a goal, agricultural activities account for nearly $70 \%$ of the population [1]. To do this, mechanization is gradually implemented. However, during harvest periods, there is overproduction which is transformed into post-harvest losses due to the lack of adequate means of conservation, thus exposing the population to famine. These post-harvest losses are estimated at $40 \%$ in underdeveloped countries [2]. It is therefore necessary to develop conservation techniques and technologies that allow people to dispose of food in all seasons. Several types of fruit and vegetable treatments for storing them for long periods while preserving their nutritional qualities have been used namely: refrigeration, freezing, freezing, smoking and drying. The latter appears to be the oldest and most widespread of these methods. It is a process of thermal extraction of a volatile substance (usually water) from a product [3]. In terms of physics, drying is most often the result of a simultaneous heat and mass transfer within the product to be dried and at the interface between this material and the drying environment [4]. This conservation technique has been the subject of several research studies in which some authors have focused on the reduction of energy consumption and the preservation of the biological quality of dried products. Thus, the work encountered focused on the through flow, the counter flow through flow and the licking flow. Among the experimental works carried out in recent years, we can cite [2] who modeled the intermittent drying of mango, [5] have studied the drying kinetics of figs; [6] evaluated the effect of treatment on the drying kinetics of okra; [7] also evaluated the drying kinetics of the fungus during fluidized bed drying; [8] studied the drying kinetics of cocoa; [9] studied the drying kinetics of apple slices and [10] determined the drying kinetics of iroko. Some authors have opted for the numerical approach. For example, [11] made an analytical study of the kinetics of mango and manioc; [12] performed a mathematical modeling of tomato drying, [13] modeled corn drying. [14] performed a mathematical modeling of the solar drying kinetics of banana, mango and cassava; [15] have made a numerical study of the drying of mangoes; [16] and [17] made a mathematical modeling of chilli drying; [18] simulated the drying of mango in forced convection. It appears from these works that the countercurrent liquefying flux has not been approached in order to improve the drying process. This is the aspect of our contribution to the study of drying kinetics. 
The main objective of our work is to study the drying kinetics of mango (Mangifera indica L.) using an airflow dryer licking counter-current. The experimental tests consist of studying the influence of the drying air temperature and the position of the rack on the drying rate. Using an empirical approach, we try to determine the kinetic model of drying. These empirical relationships can be used for the design and modeling of electrical dryers licking counter-current.

\section{Materials and Methods}

\subsection{Plant Material}

The plant material used in this work is a mango variety (Mangifera indica L.) found in the Adamawa Region of Cameroon. It is one of the seasonal fruits most produced and consumed in Cameroon. This fruit represents an important source of vitamins $\mathrm{A}$ and $\mathrm{C}$ and $\beta$ carotene for some developing African countries [19]. It has an average water content of $84 \%$ [20].

\subsection{Experimental Device}

The experimental device (Figure 1) is a forced convection electric dryer. In the airflow drying pattern licking counter-current, the convective heating air passes through the drying chamber from bottom to top. The plywood is mounted transversely so as to allow a serpentine air circulation. The trays are arranged transversely and moved in the opposite direction of the air flow during drying undergoing a licking air flow [21].

The masses of the samples are measured using a SARTORIUS brand electronic scale, type 1264 001, with a maximum load of $3000 \mathrm{~g}$ and a minimum of $5 \mathrm{~g}$ with a reading accuracy of $\pm 0.01 \mathrm{~g}$ for weighing samples during the drying operation. Four temperature probes are placed in the dryer to measure the temperature of the drying air. The operating range of this EC.50-M / N type thermostat is $-20^{\circ} \mathrm{C}$ to $99^{\circ} \mathrm{C}$ with an accuracy of $0.2^{\circ} \mathrm{C}$. The acquisition unit "Almemo 2590" has four inputs on which will be mounted thermocouples, displays the air temperature values during drying operations.

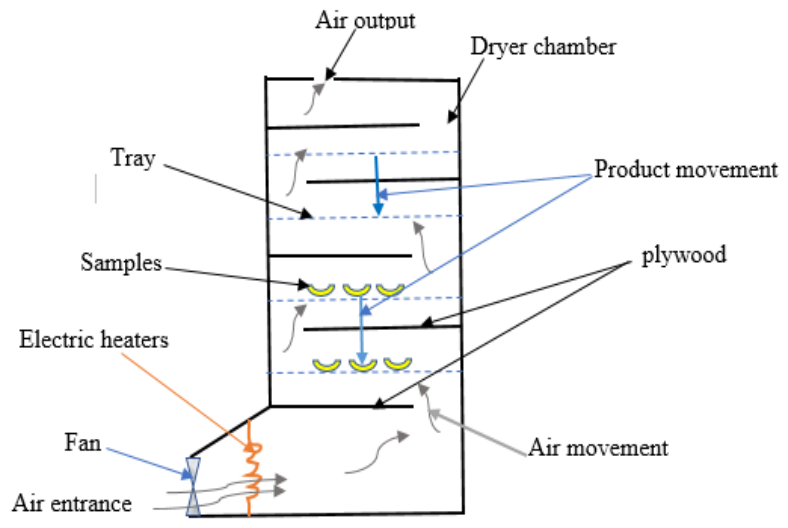

Figure 1. Configuration of the flow dryer licking countercurrent

\subsection{Methods}

The experiments took place in an electric dryer between May and June, period of harvest of mangoes in the Adamawa Region, under the following atmospheric conditions (atmosphere of the premises housing the test device installed at Ngaoundere): temperature average $25^{\circ} \mathrm{C}$, average relative humidity $75 \%$. Eighteen tests were conducted including six for each air temperature. Thus three temperature values were used: $40^{\circ} \mathrm{C}, 50^{\circ} \mathrm{C}$ and $60^{\circ} \mathrm{C}$, for an air velocity value of $0.6 \mathrm{~m} / \mathrm{s}$. The initial mass of the slices spread on each rack was on average 1000 g. For each test, the weight loss of the products is recorded.

\section{- Experimental protocol}

The mangoes are washed and then rinsed with drinking water to remove any impurities present on their surfaces. They are peeled, pitted and cut longitudinally in slices of thickness varying between $[0.3 \mathrm{~cm} ; 2 \mathrm{~cm}]$ and of length between $[1 \mathrm{~cm} ; 1.5 \mathrm{~cm}]$ with a small knife and measured with calipers. The trays are weighed every 30 minutes outside the drying chamber. The duration of each weighing varies from 80 to 90 s and deduced from the total drying time of the product. In this study, it is considered that the drying is complete for reduced water content around $20 \%$. The kinetics obtained will be adjusted using the thin-film models found in the literature and listed in Table 1.

Table 1. Thin layer mathematical models

\begin{tabular}{ll}
\hline Models & Expressions \\
\hline Newton [22,23] & $M R=\exp (-k t)$ \\
Page modified [24] & $M R=\exp \left(-(-k t)^{n}\right)$ \\
Henderson and Pabis [23] & $M R=a \cdot \exp (-k t)$ \\
Henderson and Pabis modified [25] & $M R=a \cdot \exp (-k t)+b \cdot \exp (-g t)+c \cdot \exp (-h t)$ \\
Logarithmic [26-27] & $M R=a \cdot \exp (-k t)+c$ \\
Two term [23,28] & $M R=a \cdot \exp (-k t)+b \cdot \exp \left(-k_{1} t\right)$ \\
Diffusion approximate [6,23] & $M R=a \cdot \exp (-k t)+(1-a) \cdot \exp (-k b t)$ \\
Midilli et al., [29] & $M R=a \cdot \exp \left(-k t^{n}\right)+b \cdot t$ \\
Verma et al., [28] & $M R=a \cdot \exp (-k t)+(1-a) \cdot \exp (-g t)$ \\
Wang and Singh [23,30] & $M R=1+a t+b t^{2}$ \\
\hline
\end{tabular}




\section{- Drying process}

From the masses obtained by weighing, the moisture contents in dry base are calculated by using the equation (1) [2].

$$
M_{r}=\frac{m(t)}{m_{i}}
$$

With $\mathrm{m}_{\mathrm{i}}, \mathrm{m}(\mathrm{t})$ mass of fruit respectively at initial instant and at instant $\mathrm{t}(\mathrm{kg})$.

It is important to specify that the value of the moisture contents (MR) is between 0 and 1 . The drying rate is calculated using the equation (2) and is expressed in $\mathrm{kg}$ of water $/ \mathrm{kg}$ of water.MS.min [31].

$$
\frac{d M}{d t}=\frac{M_{t}-M_{t+d t}}{d t}
$$

Where: $\mathrm{t}=$ Period drying $(\min ), \mathrm{M}_{\mathrm{t}}=$ Moisture ratio at the instant $\mathrm{t}, \mathrm{M}_{\mathrm{t}+\mathrm{dt}}=$ Moisture ratio at $\mathrm{t}+\mathrm{dt}$.

The determination of these drying parameters will allow the drawing of the different drying kinetics.

\section{- Statistical parameters}

The nonlinear regression analysis was performed using the Matlab statistical analysis tool. Although the coefficient of determination $\left(\mathrm{R}^{2}\right)$ was one of the primary criterions for selecting the best model to describe thin-layer drying curves of slices, the statistical test methods such as the reduced Khi- square $\left(\chi^{2}\right)$, root mean square error (RMSE) as described by Equation (3) and (4) were also used to evaluate the goodness of fit of the models. The lower $\chi^{2}$ and RMSE values and the higher $\mathrm{R}^{2}$ values were chosen as the basis for goodness of fit [32]. These parameters are described by the following equations (3 and 4):

$$
\begin{aligned}
\chi^{2} & =\frac{\sum_{i=1}^{N}\left(M R_{\mathrm{exp}, i}-M R_{\mathrm{pre}, i}\right)^{2}}{N-Z} \\
M S E & =\frac{1}{N} \sum_{i=1}^{N}\left(M R_{\mathrm{exp}, i}-M R_{\mathrm{pre}, i}\right)^{2} .
\end{aligned}
$$

\section{Results and Discussion}

\subsection{Temperature Distribution in the Dryer}

Figure 2 presents the profiles of the air drying temperature as a function of the position of the tray at 40 , 50 and $60^{\circ} \mathrm{C}$, the trays are numbered from bottom to top in ascending order.

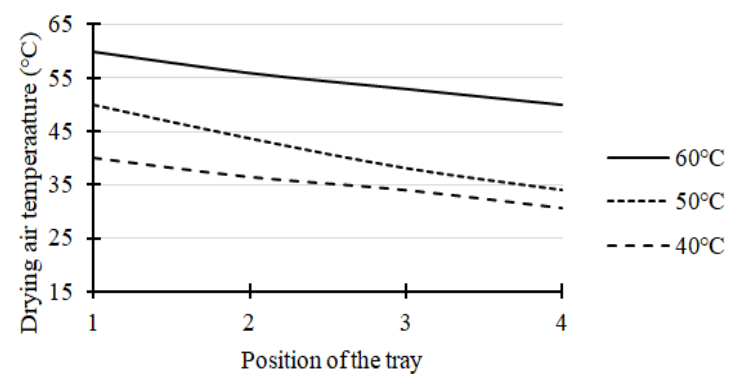

Figure 2. Drying air temperature profiles during drying licking countercurrent
The shape of the curves in Figure 2 shows that the temperature of the air decreases when moving from one rack to another in the direction of the air drying flow. This behavior of the temperature profile is consistent with the literature. Indeed, according to [1], the air drying temperature decreases after the passage of each product rack to be dried. This air temperature decreasing is due to the exchange of heat and material between the product and the air in the drying chamber. The product is wet, absorbing water vapor, the air temperature decreases. These results are similar to those of [33].

Figure 3 below presents the evolution of the air temperature as a function of time at the positions of the wires $1,2,3,4$ at temperature $60^{\circ} \mathrm{C}$.

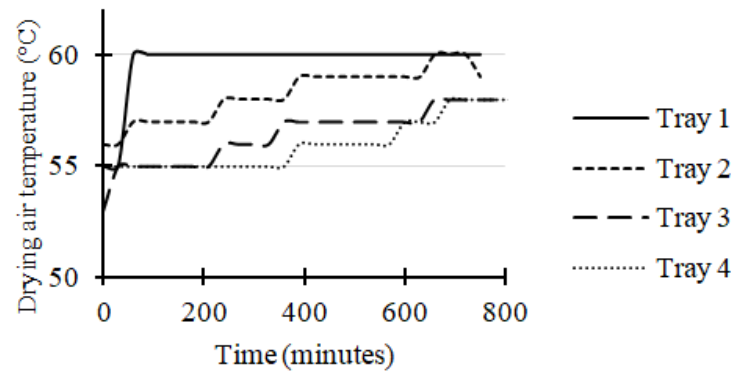

Figure 3. Drying air temperature profiles as a function of time for different positions of the tray

With regard to Figure 3, it can be seen that the first 90 minutes correspond to a rise in the temperature of the air in the dryer. The first tray reaches its stability zone (constant temperature) before the other trays. This can be explained by the fact that the air reaches the other trays being saturated (the product transmits its water content to the air by vaporization). Therefore, they dry less quickly than the first. The evaporation power of the air is more important at the level of the first tray. Similar results were obtained by $[34,35,36]$.

\subsection{Influence of the Temperature on the Kinetics of Drying in the Second Tray}

Figure 4 illustrates the moisture content profiles reduced of the samples of mangoes dried in licking countercurrent mode, if the samples are exposed to the ambient air for the tempered period.

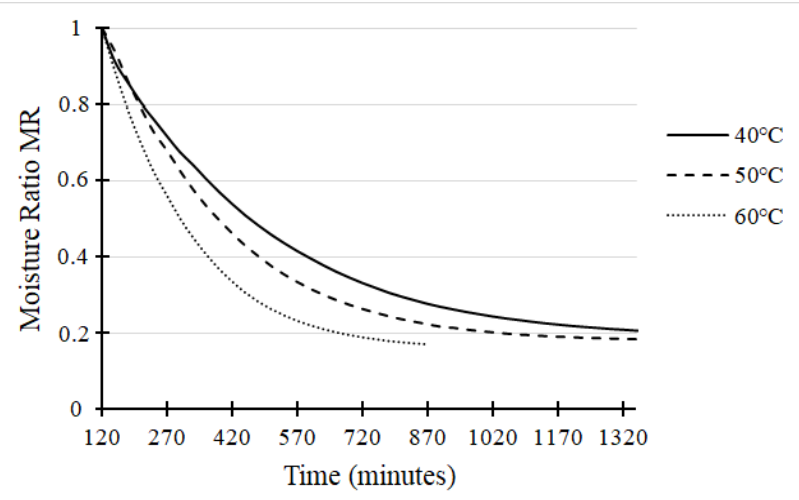

Figure 4. Moisture ratio profiles of mango in a licking countercurrent mode at 40,50 and $60^{\circ} \mathrm{C}$ on the second tray 
The interpretation of these curves of Figure 4 shows that more the air temperature increases; more the drying operation duration is low. Thus, in the case of mango, the drying time goes from 870 minutes at $60^{\circ} \mathrm{C}$ to 1440 minutes at $40^{\circ} \mathrm{C}$, resulting in a water content reduced by $20 \%$. This results on the one hand from the increase of the heat flux brought by the air to the product and on the other hand from the acceleration of the internal migration of the water. Increasing the temperature of the product not only changes the activity of the water but also influences the coefficient of diffusion of moisture. Similar results were found by [31] on pineapple slices; [37] on corn and [38] on tomato.

\subsection{Influence of Rack Position on Drying Kinetics}

Figure 5 illustrates the influence of the position of the tray on the moisture ratio profiles of the mango as a function of time during drying licking countercurrent at $60^{\circ} \mathrm{C}$.

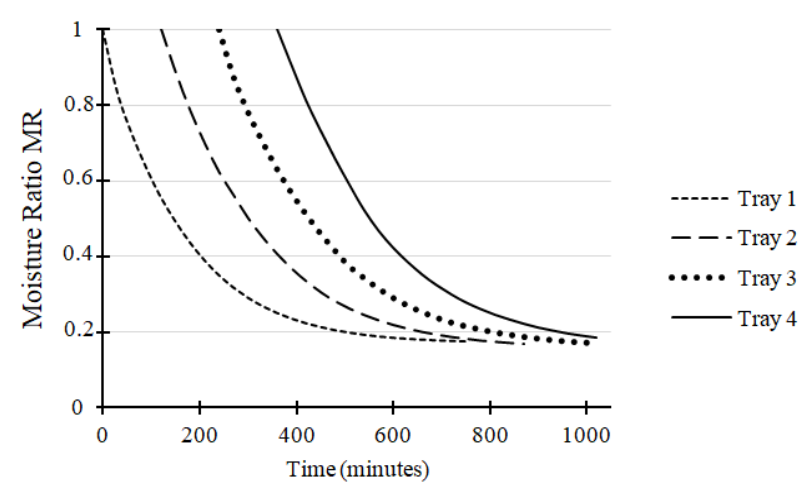

Figure 5. Moisture ratio profiles of mango in a licking countercurrent mode at $60^{\circ} \mathrm{C}$ on the different positions of trays

The curves in Figure 5 appear as a single curve plotted with different time frames on a single graph. These curves show that despite the introduction of trays undergoing a flow of air licking countercurrent, at different times (2 hours of intervals), the kinetics have the same pace, but the products on the trays do not reach not their equilibrium water content at the same time. Moreover, the observation of these curves allows us to see that at the end of the drying, we obtain homogeneous products. A translation on the time scale of 2 hours allows these curves to be superimposed.

Figure 6 illustrates the drying profiles of mango in a licking countercurrent mode at $60^{\circ} \mathrm{C}$ for four positions of trays (tray 1, 2, 3, 4 and sum of tray).

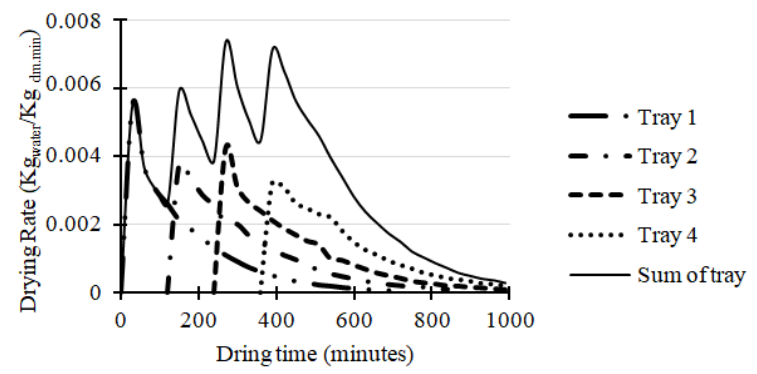

Figure 6. Drying profiles of mango in a licking countercurrent mode at $60^{\circ} \mathrm{C}$ for different positions of trays
The curves of Figure 6 above show that the drying rate profiles increases at the beginning of drying during the average of the first 30 minutes and decreases after this time at all the dryer trays, regardless of the position of the tray inside the dryer. The curves all have differences (the difference between the curves is considerable). The difference between these curves is less pronounced at the end of drying. That is to say that the curves tend to be superimposed at the end of drying; which leads us to conclude on the homogeneity of the products resulting from this drying. It is shown that the evolution of this drying rate over time presents the existence of two phases of drying. The phase of increase of the speed corresponds to the free water of the product. The extraction of this water in mango requires less heat than that required to extract bound water. Similar observations have been presented in the literature by $[2,28,32,39,40]$.

\subsection{Modeling}

\subsubsection{Values of Statistical Parameters}

Table 2 below presents the results obtained from the adjustments of the models selected in the context of our work.

Table 2. Values of statistical parameters of different thin layer models for countercurrent airflow licking drying.

\begin{tabular}{|c|c|c|c|c|}
\hline \multirow{2}{*}{$\mathbf{T}\left({ }^{\circ} \mathbf{C}\right)$} & \multirow{2}{*}{ Modèles } & \multicolumn{3}{|c|}{ Statistical parameters } \\
\hline & & $\mathbf{R}^{2}$ & RMSE & $\chi^{2}$ \\
\hline \multirow{10}{*}{40} & Newton & 0.9989 & 0.0095 & $8.9369 .10^{-5}$ \\
\hline & $\begin{array}{l}\text { Henderson et } \\
\text { Pabis }\end{array}$ & 0.9991 & 0.0081 & $6.5752 .10^{-5}$ \\
\hline & Logarithmique & 0.9998 & 0.0041 & $1.6791 .10^{-5}$ \\
\hline & Two term & 0.9996 & 0.0053 & $2.8271 .10^{-5}$ \\
\hline & $\begin{array}{c}\text { Diffusion } \\
\text { approximative }\end{array}$ & 0.9991 & 0.0082 & $6.7529 .10^{-5}$ \\
\hline & Midilli et al. & 0.9999 & 0.0021 & $4.6188 .10^{-6}$ \\
\hline & Page modifié & 0.9992 & 0.0079 & $6.2079 .10^{-5}$ \\
\hline & $\begin{array}{l}\text { Henderson et } \\
\text { Pabis modifié }\end{array}$ & 0.9991 & 0.0082 & $7.3487 .10^{-5}$ \\
\hline & Verma et al. & 0.9998 & 0.0039 & $1.4931 .10^{-5}$ \\
\hline & Wang et Singh & 0.9590 & 0.0553 & 0.0031 \\
\hline \multirow{10}{*}{50} & Newton & 0.9989 & 0.0095 & $8.9369 .10^{-5}$ \\
\hline & $\begin{array}{c}\text { Henderson et } \\
\text { Pabis }\end{array}$ & 0.9998 & 0.0096 & $9.1448 .10^{-5}$ \\
\hline & Logarithmique & 0.9998 & 0.0038 & $1.4220 .10^{-5}$ \\
\hline & Two term & 0.9988 & 0.0097 & $9.8482 .10^{-5}$ \\
\hline & $\begin{array}{c}\text { Diffusion } \\
\text { approximative }\end{array}$ & 0.9993 & 0.0077 & $5.9275 .10^{-5}$ \\
\hline & Midilli et al., & 0.9998 & 0.0037 & $1.4046 .10^{-5}$ \\
\hline & Page modifié & 0.9991 & 0.0085 & $7.3034 .10^{-5}$ \\
\hline & $\begin{array}{l}\text { Henderson et } \\
\text { Pabis modifié }\end{array}$ & 0.9988 & 0.0097 & $1.0669 .10^{-4}$ \\
\hline & Verma et al., & 0.9998 & 0.0042 & $1.7490 .10^{-5}$ \\
\hline & Wang et Singh & 0.9596 & 0.0562 & 0.0032 \\
\hline \multirow{10}{*}{60} & Newton & 0.9991 & 0.0080 & $6.4066 .10^{-5}$ \\
\hline & $\begin{array}{c}\text { Henderson et } \\
\text { Pabis }\end{array}$ & 0.9994 & 0.0065 & $4.2047 .10^{-5}$ \\
\hline & Logarithmique & 0.9996 & 0.0053 & $2.7624 .10^{-5}$ \\
\hline & Two term & 0.9996 & 0.0053 & $2.8271 .10^{-5}$ \\
\hline & $\begin{array}{c}\text { Diffusion } \\
\text { approximative }\end{array}$ & 0.9991 & 0.0082 & $6.9887 .10^{-5}$ \\
\hline & Midilli et al., & 0.9997 & 0.0047 & $2.2230 .10^{-5}$ \\
\hline & Page modifié & 0.9997 & 0.0049 & $2.4360 .10^{-5}$ \\
\hline & $\begin{array}{l}\text { Henderson et } \\
\text { Pabis modifié }\end{array}$ & 0.9999 & 0.0023 & $5.7560 .10^{-5}$ \\
\hline & Verma et al., & 0.9909 & 0.0258 & $6.9405 .10^{-5}$ \\
\hline & Wang et Singh & 0.9256 & 0.0736 & 0.0054 \\
\hline
\end{tabular}


One note that in general the values of $\mathrm{R}^{2}, \mathrm{MSE}$, and $\chi^{2}$ of the models selected for different temperatures of the experiments varied respectively between: 0.925 - 0.999 ; $0.0021-0.0736$ and $4.10^{-6}-0.0054$.

For all models, the $\mathrm{R}^{2}$ value was greater than 0.90 , indicating a good fit [28].

The statistical parameters obtained, in order to check the fit of the chosen models to the experimental results, are presented in Table 2. The best model is that with a maximum correlation coefficient that tends to 1 and a minimum standard error that tends to 0 .

\subsubsection{Expressions of the Model Parameters}

The experimental moisture ratio is plotted as a function of time in Figure 7 for different temperatures and then adapted to the ten mathematical drying models. It is clear from Table 2 that the best model with maximum $\mathrm{R}^{2}$ and the smallest values of MSE and $\chi^{2}$ do indeed correspond to Midilli et al. Therefore, this model is well suited to represent the evolution of the reduced water content of mango slices under these conditions. It is the same case with [6] on okra; [32] on mangoes; [41,42] on apple slices.

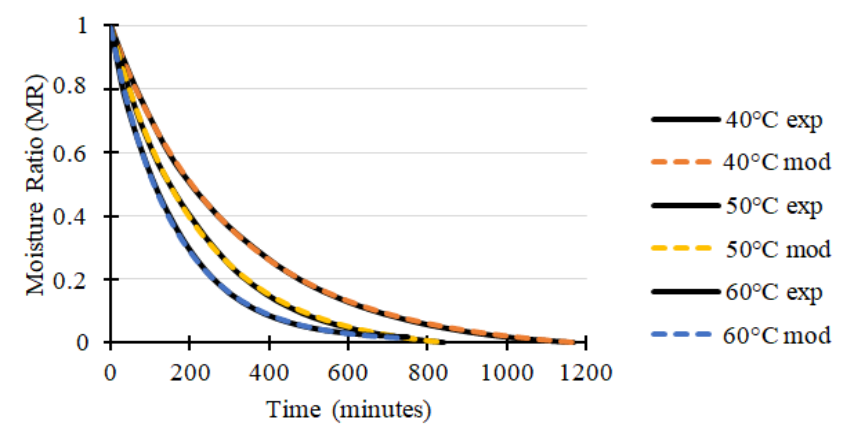

Figure 7. Variation of the experimental and predicted moisture ratio by the Midilli et al., model, during drying licking countercurrent at 40, 50 and $60^{\circ} \mathrm{C}$

In the airflow drying licking countercurrent, the effect of temperature on the drying constants of the Midilli et al., was taken into account by developing the relation between these constants and the drying temperature. The regression equations relating the constants of the selected model and the drying temperature are the following by the equations from 5 to 9 below.

The equation of the best model (Midilli et al.,) is of the form:

$$
M R=a \cdot \exp \left(-k t^{n}\right)+b \cdot t
$$

with:

$$
\begin{gathered}
a=0.000003 T^{2}-0.0007 T+1.0256 \\
b=0.0000002 T^{2}-0.00002 T+0.0004 \\
k=0.000007 T^{2}-0.0006 T+0.0158 \\
n=-0.0002 T^{2}+0.0207 T+0.4596
\end{gathered}
$$

Comparing the experimental moisture ratio of mango values with the moisture ratio values of the Midilli et al., model, one notice a good fit between the established model and the experiment (Figure 8).

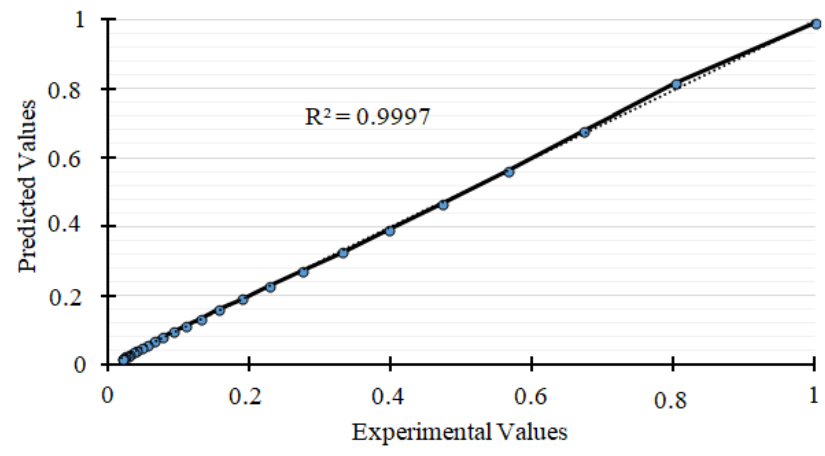

Figure 8. Comparison between experimental and predicted values

\section{Conclusion}

In this work, the drying rate of mango was carried out in a modular electric airflow dryer licking countercurrent for three temperatures $\left(40,50\right.$ and $\left.60^{\circ} \mathrm{C}\right)$. According to the results of multiple linear regression analyzes, among the ten models tested, the Midilli et al., drying model is suitable for describing the drying behavior of mango in counteracting leach flow. The coefficients of this model are very important in the transfer of moisture, because they depend on the air temperature. The evolution of this air temperature shows that it influences the extraction of water in the product. The drying kinetics curves showed the existence of two drying phases. That is, the absence of the constant speed phase. Countercurrent leach flow drying produces homogeneous products. The drying characteristic curve obtained makes it possible to generalize the mango drying kinetics data and to optimize the sizing of drying driers adapted to the drying of mangoes.

\section{References}

[1] Kuitche, A., Kouam, J., Edoun, E., Modélisation du profil de température dans un séchoir construit dans l'environnement tropical, Journal of Food Engineering. 76, pp 605-610. 2006.

[2] Tetang, F.A., Edoun, M., Kuitche, A., and Zeghmati, B., Experimental drying kinetics of mango slices (Mangifera indica L.), Amelie under intermittent conditions. International Journal of Thermal Technologies. pp 203-211. 2016.

[3] Mujumdar, A.S., Handbook of Industrial Drying. Taylor and Francis Group, L.L.C., Third Edition. 2006.

[4] Kouhila, M., Etude expérimentale et théorique des cinétiques de séchage convectif partiellement solaire des plantes médicinales et aromatiques (menthe, verveine, sauge et eucalyptus) de la région de Marrakech. Thèse de Doctorat, Université Cadi Ayyad, Marrakech. 2001.

[5] Babalis, S.J, Papanicolaou, E., Kyriakis, N., Belessiotis, V.G., Evaluation of thin-layer drying models for describing drying kinetics of figs (Ficus carica), Journal of Food Engineering. 75 205-214. 2006.

[6] Kuitche, A., Edoun, M., Takamte, G., Influence of Pre-treatment on Drying on the Drying Kinetic of a Local Okro (Hibiscus ersculentus) Variety. World Journal of Dairy \& Food Sciences. 2007.

[7] Arumuganathan, T., Manikantan, M.R., Rai R.D., Anandakumar S., Khare, V., Mathematical modeling of drying kinetics of milky mushroom in a fluidized bed dryer. International agrophysics. 2009.

[8] Hii, C.L., Law, C.L, Cloke, M., Modeling using a new thin layer drying model and product quality of cocoa. Journal of Food Engineering. 90. pp 191-198. 2009. 
[9] Seiiedlou, S., Ghasemzadeh, H.R, Hamdami, N, Talati, F., Convective drying of apple: mathematical modeling and determination of some quality parameters. International Journal of Agriculture \& Biology. 2010.

[10] Monkam, L., Ayina, O.L.M, Chugoua, N.A., and Mekongo, A.F., Determination of the diffusion coefficient and the activation energy of water desorption in IROKO wood (Chlorophora excelsa), during a conductive drying. International Journal of Thermal Technologies ISSN 2277-4114. 39. 2013.

[11] Hernandez, J.A, Pavon, G., Garcia, M.A., Analytical solution of mass transfer equation considering shrinkage for modeling fooddrying kinetics, Journal of Food Engineering. 45 pp 1-10. 2000.

[12] Sacilik, K, Rahmi, K, Ahmet, K.E., Mathematical modelling of solar tunnel drying of thin layer organic tomato. Journal of Food Engineering. 73 pp 231-238. 2006.

[13] Andriazafimahazo, L.F., Andrianelson, R., Bertin, R., Zeghmati, B., Modélisation de la vitesse de séchage du maïs. Afrique science 05(2). pp 173-183 ISSN. 2009.

[14] Koua, K.B., Wanignon, F.F., Gbaha, P., Siaka, T., Mathematical modelling of the thin layer solar drying of banana, mango and cassava. Energy. 34. pp 1594-1602. 2009.

[15] Villa-Corrales, L., Flores-Prieto, J.J., Xaman-Villasenor, J.P., Garcia-Hernandez E., Numerical and experimental analysis of heat and moisture transfer during drying of Ataulfo mango, Journal of Food Engineering, 98, 198-206. 2010.

[16] Barati, E., Esfahani, J.A., A new solution approach for simultaneous heat and mass transfer during convective drying of mango. Journal of Food Engineering. 102. 2011.

[17] Renata, C.R., Ludmilla, S.B., Mateus, L.L., Jacqueline S.R., Ivano A.D., Diego P.R.A., Modelagem matemática da secagem da pimento Cumari do Pará, Revista Brasileira de Engenharia Agrícola e Ambiental v.15, n.4, p.347-353. 2011.

[18] Takamte, G., Edoun, M., Monkam, L., Kuitche, A., Kamga R., Numerical Simulation of Convective Drying of Mangoes (mangifera Indica L.) under Variable Thermal Conditions. International Journal of Thermal Technologies. ISSN 2277-4114. pp48-52. 2013.

[19] Rankins, J., Sathe, S.K., Spicer, M.T., Solar Drying of Mangoes: Preservation of an Important Source of Vitamin A in FrenchSpeaking West Africa. Journal of the American Dietetic Association. 108 : 986-990. 2008

[20] Tetang, F.A., Modélisation des transferts de chaleur et de matière lors du séchage intermittent des fruits à forte teneur en eau Application à la mangue 'Amélie'. Thèse de Doctorat, Université de Ngaoundéré. 224p. 2018.

[21] Matuam, B., Edoun, M., Kuitche, A., Zeghmati, B., Experimental evaluation of the thermal performance of dryer airflow configuration. International Journal of Energy Engineering 5(4): 80-86. 2015

[22] Amellal, H., and Benamara, S., Vaccum Drying of Common Date Pulp Cubes, Drying Technology, Vol. 26, N³, pp. 378-382. 2008.

[23] Togrul, I.T., and Phelivan, D., Modelling of Drying Kinetics of Single Apricot, Journal of Food Engineering, Vol. 58, $\mathrm{N}^{\circ} 1$, pp. 23-32. 2003.

[24] Chenarbon, H., Ahmadi, Minaei S., Bassiri A.R., Almassi M., Arabhosseini, A., Modeling of drying St. John’s wort (Hypericum perforatum L.) leaves. Journal of Medicinal Plants Research. Vol. 5(1), 126-132. 2011.

[25] Karathanos, V.T., and Belessiotis, V.G., Application of Thin Layer Equation to Drying Data of Fresh and Semi-Dried
Fruits, Journal of Agricultural Engineering Research, Vol.74, pp.1389-1401. 1999.

[26] Boubekri, A., Benmoussa, H., Mennouche, D., Solar Drying Kinetics of Date Palm Fruits Assuming a Step-Wise Air Temperature Change, Journal of Engineering Science and Technology, Vol. 4, N³, pp. 292-304. 2009.

[27] Akpinar, E.K., Determination of Suitable Thin Layer Drying Curve Model for Some Vegetables and Fruits, Journal of Food Engineering, Vol. 73, $\mathrm{N}^{\circ} 1$, pp. 75-84. 2006.

[28] Doymaz, I., Sun Drying of Figs: an Experimental Study, Journal of Food Engineering, Vol. 71, N4, pp. 403-407. 2005.

[29] Midilli, A., Kucuk, H., Yapar, Z.A., New model for single layer drying. Drying Technology, 20(7), 1503-1513. 2002.

[30] Yaldiz, O., Ertekin, C., Uzun, H.I., Mathematical modeling of thin layer solar drying of Sultana grapes. Energy 26(5): 457-465. 2001.

[31] Edoun, M., Développement d'un outil d’aide à la conception de procédés de séchage à petite échelle en zone tropicale humide, thèse soutenue en vue de l'obtention du Doctorat/Ph.D. en Génie des Procédés à l’Ecole Nationale Supérieure des Sciences AgroIndustrielles (ENSAI). 2010.

[32] Edoun, M., Matuam, B., Kuitche, A., Mathematical Modelling of Thin Layer Mangoes (Mangifera indica L.) Drying Process. International Journal of Current Engineering and Technology. 2014.

[33] Benaouda, N., Boulemtafes, A., Balhamel, M., Etude du comportement thermique et dynamique d'un séchoir solaire, $12^{\text {èmes }}$ Journées Internationales de Thermique, Tanger, Maroc du 15 au 17 Novembre 2005.

[34] Ben, A.E., Ben, M.S., Sassi, M., Modeling convective and intermittent drying of agricultural product, Revue des Energies Renouvelables. Vol. $13 \mathrm{~N}^{\circ} \mathrm{l}$ 123-132, 2010.

[35] Remache, L., et Belhamri, A., Modélisation du séchage par convection, Revue des énergies renouvelables CISM '08, pp 289 297. 2008.

[36] Touati, B., Kouhila, M., Touhami, A., Etude de l'influence de quelques paramètres sur la température et l'humidité du système air-produit lors du séchage solaire des feuilles de menthe. $12^{\text {èmes }}$ Journées Internationales de Thermique, Tanger, Maroc du 15 au 17 Novembre 2005.

[37] Janas, S., Malumba, P., Deroanne, C., Béra, F., Comparaison d'un modèle empirique et d'un modèle physique de séchage de grains de maïs en lit fluidisé, Biotechnol. Agron. Soc. Environ. 14(3), 389-398. 2010.

[38] Boughali, S., Bouchekima, B., Nadir, N., Mennouche, D., Bouguettaia, H., Bechki, D., Expérience du séchage solaire dans le Sahara Septentrional Est Algérien, Revue des Energies Renouvelables SMSTS'08. Alger pp105 - 110. 2008.

[39] Minaei, S., Motevali, A., Najafi, G., Seyedi, S.R.M., Influence of drying methods on activation energy, effective moisture diffusion and drying rate of pomegranate arils (Punica Granatum), Australain Journal of crop Science. 6(4): 584-591. 2011.

[40] Doymaz, I., and Pala, M., The thin-layer drying characteristics of corn. Journal of Food Engineering, 60, 125-130. 2003.

[41] Meisami-asl, E., Rafiee, S., Keyhani, A., Tabatabaeefar A., Mathematical Modeling of Moisture Content of Apple Slices (Var. Golab) During Drying, Pakistan Journal of Nutrition 8 (6): 804-809. 2009.

[42] Toujani, M., Hassini, L., Azzouz, S., Belghith, A., Experimental study and mathematical modeling of apple convective drying, European Drying Conference EuroDrying'. 2011. 